\title{
An Experimental Petrological Study of Gabbro in Chintan, Taipei County, at Atmospheric Pressure
}

\author{
Jin-Wei Hsu ${ }^{1}$, Teh-Ching Liu ${ }^{1, *}$, and Yoshiyuki Iizuka ${ }^{2}$ \\ ${ }^{1}$ Department of Earth Sciences, National Taiwan Normal University, Taipei, Taiwan, ROC \\ ${ }^{2}$ Institute of Earth Sciences, Academia Sinica, Taipei, Taiwan, ROC
}

Received 12 November 2008, accepted 8 April 2009

\begin{abstract}
A gabbro from Chintan, Sindian, was subjected to experiments at atmospheric pressure to study the fractional crystallization of the gabbroic melt. The range of experimental temperatures was from 1120 to $1262^{\circ} \mathrm{C}$, and the durations were from about 16 to 150 hours. The mineral phases and the glass compositions in the quenching products were analyzed with the SEM-EDS.

The experimental results showed that the liquidus temperature of the gabbro of Chintan is $1261{ }^{\circ} \mathrm{C}$. Fe-Ti oxides crystallized at $1261^{\circ} \mathrm{C}$. Plagioclase and chromite crystallized at 1233 and $1196^{\circ} \mathrm{C}$, respectively. Finally, pyroxene crystallized at $1178^{\circ} \mathrm{C}$. The solidus temperature is estimated to be about $1110^{\circ} \mathrm{C}$ and the melting interval is about $151^{\circ} \mathrm{C}$. By comparing the results of the runs with $\mathrm{Au}_{75}-\mathrm{Pd}_{25}$ capsules, the iron loss of melt to the platinum envelopes at $1238^{\circ} \mathrm{C}$ over 18 hours can be neglected.

The fractional crystallization of the gabbroic melt at atmospheric pressure is controlled by iron-titanium oxides, plagioclase, chromite, and pyroxene. The differentiation trend of the gabbroic melts moves around in the center of the AFM diagram and can not fractionate into microsyenitic and alkali feldspar syenitic melts on the ground.
\end{abstract}

Key words: Gabbro, Chintan, Experiment, Melt

Citation: Hsu, J. W., T. C. Liu, and Y. Iizuka, 2010: An experimental petrological study of gabbro in Chintan, Taipei County, at atmospheric pressure. Terr. Atmos. Ocean. Sci., 21, 267-276, doi: 10.3319/TAO.2009.04.08.01(TT)

\section{INTRODUCTION}

Chintan is located in the south of Sindian city, Taipei County, near the boundary of the Taipei basin and the Western foothills of Taiwan. The major rock formations in this area are sedimentary rocks of the Tertiary Period (Fig. 1). Fragmentary volcanic activities occurred in the Neogene Period. The eruption of these volcanics cut across Tertiary sedimentary strata and formed as basaltic rocks in western Taiwan. These igneous rocks often occurred with graben topography (Sun 1982). The rock types of igneous rocks in western Taiwan include alkali basalts and tholeiites, in which alkali basalts can be further categorized as basanitoids, alkali olivine basalts and teschenites (Chen 1990).

Ichimura (1929) first proposed the term "alkali syenites" and reported that the alkali syenites occurred as a dike or sill in the Chintan area (Ichimura 1943; Yen 1954). The dike and

\footnotetext{
* Corresponding author

E-mail:liutc@ntnu.edu.tw
}

sill occurred in the Mushan Formation which was formed in the late Oligocene to the early Miocene Periods. Chen (1998) re-studied the diked and silled igneous rocks which were described by Ichimura $(1929,1943)$ in Chintan. Chen (1998) found that alkali feldspars are common in Ichimura's alkali syenites. Also, Ti-augite is present while aegirine is absent. Therefore, Chen (1998) proposed microsyenite for the fine-grained texture to replace alkali syenite described by Ichimura $(1929,1943)$ and Yen $(1954)$.

According to the linear trends in major and trace elements, REE distribution patterns and Sr- and Nd-isotopes, Chen (1998) inferred that the intrusive magma in Chintan underwent in-situ mineral separation when intrusion occurred. After mineral separation, the teschenite crystallized from original magma in the base; the syenite groups represent residual melt. These residual melts segregated alkali feldspar syenite and microsyenite by mineral segregation. There are no teschenites visible in the sill. Chen (1998) pos- 
tulated that the teschenites are either concealed in the unexposed part of the sill, or that they have already been separated from the melt and emplaced elsewhere. The age of intrusion of Chintan was also reported by Chen (1998). By using the Ar-Ar method, the ages of dike and sill are $11.2 \pm$ 0.5 and $21.2 \pm 0.9 \mathrm{Ma}$, respectively.

The locality of the sample in this study is also shown by a star mark in Fig. 1. The exposure is at about 600 meters south of the Chintan Bridge on the road to Wulai. The outcrop is exposed above a concrete wall and the occurrence, dike or sill, of the collected gabbro is not clear.

In this study, the melting experiments of the gabbro at atmospheric pressure were conducted to study the crystallization process of the gabbroic melt. The fractional crystallization trend of the gabbroic melt will be discussed.

\section{EXPERIMENTAL METHODS}

\subsection{Starting Material}

In order to model the fractionation of the gabbroic melt at Chintan, Sindian, about $6 \mathrm{~kg}$ of gabbro samples from Chintan was collected. The weathered parts of the gabbro sample were trimmed off. The color, crystal size and texture of the gabbro were observed.

The rock sample was crushed and pulverized into a powder, the size of which is all under 200 meshes. These fine powders were kept in a desiccator as the starting material for the experiments.

\subsection{Apparatus and Procedures}

A slab of gabbro was cut into a thin section. By using polarizing microscope "Axioplan 7082", the texture of rock was observed and the minerals were identified. The albite twins were present in the thin section. The plagioclase compositions (anorthite contents) were estimated by the MichelLévy Method (Tobi and Kroll 1975; Nesse 1991).

To determine the composition of the whole rock, a glassy disk was made from a fused mixture of rock powder and flux $\left(\mathrm{Li}_{2} \mathrm{~B}_{4} \mathrm{O}_{7}\right)$. It was examined by X-ray fluorescence (XRF) spectroscopy at the Department of Geosciences, National Taiwan University. The analytical settings, standards, and mass absorption corrections for the analysis were the same as described by Lee et al. (1997). The CIPW norm of rock was calculated by using the Igpet 06 computer program. Igpet 06 is a commercial software supplied by Terra Softa Inc., New Jersey, USA.

The rock powder was encased in platinum envelopes and was put into a high temperature vertical-quenched furnace. In order to test the effects of iron loss of the sample to the platinum envelopes, two runs were made with $\mathrm{Au}_{75}-\mathrm{Pd}_{25}$ capsules. At the end of the run, the run products were quenched in water. The range of the experimental duration in this study is from about 16 to 150 hours. The details of the melting experimental techniques at atmospheric pressure were the same as that reported by Liu et al. (1997).

All temperatures were measured using a R-type ther-

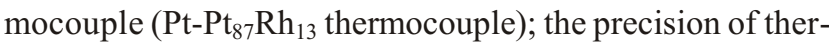
mocouple is $\pm 1{ }^{\circ} \mathrm{C}$. All temperatures were corrected to be on the International Practical Temperature Scale of 1968 (Biggar 1972) based on the calibration with the melting point of synthetic diopside $\left(\mathrm{CaMgSi}_{2} \mathrm{O}_{6}\right)$. The temperatures read from the thermocouple were incremented $8^{\circ} \mathrm{C}$ to obtain the experimental temperatures.

\subsection{Identification and Analysis of Phases}

Experimental charges were mounted in epoxy and polished to make a section. The mineral phases in the run products were first identified microscopically in reflected

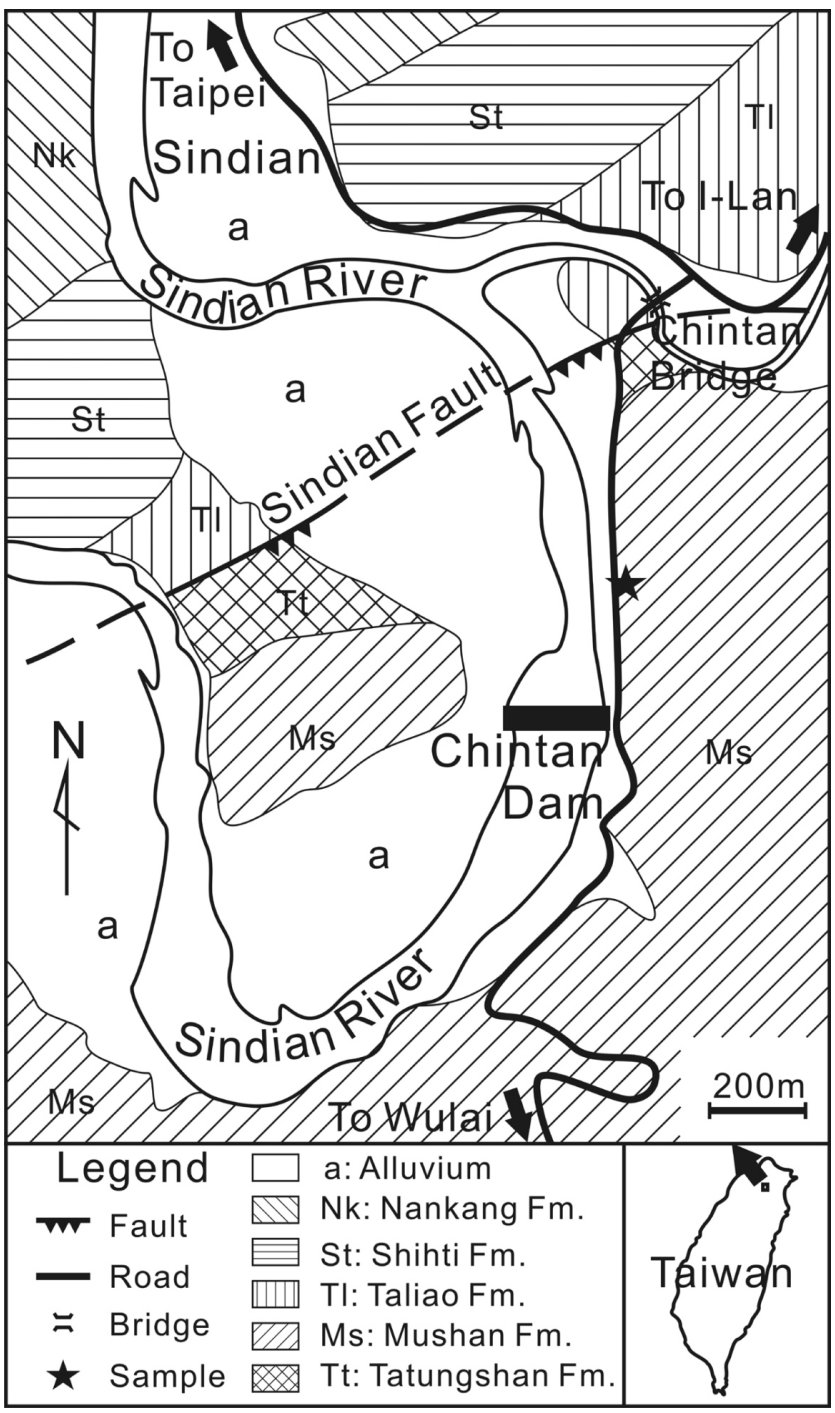

Fig. 1. A simplified geological map of the Chintan area. The route and location of outcrops modified from Ichimura (1943) and Chen (1998). The geological map modified from Lin (2000). 
light. The phases were identified according to characteristic relief, reflectivity, and crystal habit.

A scanning electron microscope (SEM: JEOL JSM6360LV) equipped with an energy dispersive X-ray spectrometer (EDS: Oxford Instruments, INCA-300) was used with $15 \mathrm{kV}$ acceleration voltage and $0.18 \mathrm{nA}$ in the primary electron beam current under low-vacuum conditions (25 Pascal). The points to be analyzed were selected under the back-scattered electron image. Grains of minerals in the quenched products chosen for analysis were usually larger than $10 \mu \mathrm{m}$ in diameter and the analyzed glass pools were usually larger than $30 \mu \mathrm{m}$ in diameter. Minerals were identified based on comparisons of the $\mathrm{x}$-ray spectra with those of chemicallyknown minerals (Iizuka et al. 2005). Chemical compositions of elements present in amounts $>1 \%$ by weight in RSD were analyzed with a $1 \mu \mathrm{m}$ electron beam spot for 100 seconds. All iron is measured as ferrous iron $\left(\mathrm{Fe}^{2+}\right)$. The quantitative data were corrected to be oxide compositions and the total compositions were normalized to 100 percent. The Igpet 06 computer program was also used to calculate the CIPW norm of the glasses.

\section{RESULTS AND DISCUSSION}

\subsection{The Gabbro of Chintan}

The texture of gabbro is microcrystalline, diabasic, and granular. Most of minerals grains are less than $1 \mathrm{~mm}$. The thin sections were observed by using polarized microscope "Axioplan 7082". Albite twins are mainly present in plagioclase. Most of the plagioclase grains are about $0.5 \mathrm{~mm}$ in diameter, but some grains are up to $1.5 \mathrm{~mm}$. The diameters of pyroxene are about 2 to $3 \mathrm{~mm}$. In addition, there are slender and opaque $\mathrm{Fe}$-Ti oxides with lengths of 0.1 to $0.5 \mathrm{~mm}$.

Under the microscope, the plagioclases in the rock were estimated to be about $65 \%$ of the content. The content of $\mathrm{Fe}-\mathrm{Ti}$ oxides is about $20 \%$. Also, $15 \%$ of pyroxene is present. Because part of the plagioclase and pyroxene were weathered, about $10 \%$ of clay minerals were present in the rock. Due to the alteration of the minerals of the rock, the whole rock composition of the tested sample can be slightly different from the original composition of the gabbro.

By using the Michel-Lévy Method to determine plagioclase composition with albite twins in thin section, the anorthite (An) content of the gabbro is estimated to be between $\mathrm{An}_{28}$ and $\mathrm{An}_{73}$. The anorthite contents of teschenite and alkali basalt in Chintan are from 40 to $73 \%$ (Chen 1998), indicating that the fractionation was significant during the cooling of the alkali basaltic magma in Chintan.

\subsection{Whole Rock Chemistry}

The whole rock compositions analyzed by XRF are listed in Table 1. Compared with the basalt analyses by
Chen (1998), they are very similar. In addition, the loss on ignition (L.O.I.) of gabbro in this study is as much as that of Chen's basalts (1998).

In the CIPW norm calculation (Table 1), the gabbro of this study is quartz-normative and hypersthene-normative. The gabbro in this study has a slightly higher diopside norm, and lower quartz and hypersthene norms than Chintan basalts (Chen 1998). They are all classified as quartz tholeiite in the basalt tetrahedron (Yoder and Tilley 1962). The composition of gabbro in this study was also plotted in an alkali-silica diagram (Fig. 2). The composition of gabbro in this study was classified as basalt.

\subsection{Experimental Runs at Atmospheric Pressure}

Twenty-one melting experimental runs with platinum envelopes were performed to locate the liquidus temperature, the solidus temperature, and the melting interval of the melt. The results are listed in Table 2 including two runs with $\mathrm{Au}_{75}-\mathrm{Pd}_{25}$ capsules (CT-52 and CT-51). The range of experimental temperatures is from 1120 to $1262^{\circ} \mathrm{C}$. In the run at $1120^{\circ} \mathrm{C}$, trace amount of glass was observed. Therefore, the solidus temperature of gabbro was deduced to be about $1110^{\circ} \mathrm{C}$. The melting interval is estimated to be about $151{ }^{\circ} \mathrm{C}$.

The experimental results showed that the liquidus temperature of the gabbro of Chintan is $1261^{\circ} \mathrm{C}$. The crystallized phases increase with decreasing temperature. The FeTi oxides crystallized at $1261^{\circ} \mathrm{C}$. Plagioclase and chromite crystallized at 1233 and $1196^{\circ} \mathrm{C}$, respectively. Finally, pyroxene crystallized at $1178^{\circ} \mathrm{C}$. Therefore, the crystallization sequence of the gabbroic melt at atmospheric pressure is Ti-Fe oxides, plagioclase, chromite, and pyroxene, as shown in Fig. 3.

In order to test the effects of iron loss from the sample to the platinum envelopes, the experiment (CT-51) at $1238^{\circ} \mathrm{C}$ was conducted with $\mathrm{Au}_{75}-\mathrm{Pd}_{25}$ capsule to be compared with the run (CT-49) at the same temperature and duration (Table 2). The composition of glasses in CT-49 (with Pt envelope) and CT-51 (with $\mathrm{Au}_{75}-\mathrm{Pd}_{25}$ capsule) are very similar (Table 3 and Fig. 4). This indicates that the iron loss to the platinum envelopes at $1238^{\circ} \mathrm{C}$ over 18 hours is almost the same as those to the $\mathrm{Au}_{75}-\mathrm{Pd}_{25}$ capsule. Another experiment at a higher temperature $\left(1262^{\circ} \mathrm{C}\right)(\mathrm{CT}-52)$ was also repeated with $\mathrm{Au}_{75}-\mathrm{Pd}_{25}$ capsules and compared with the run $\mathrm{CT}-34\left(1262^{\circ} \mathrm{C}\right)$. The total $\mathrm{FeO}$ content of the glass of CT-34 (with Pt envelope) is less than the $\mathrm{FeO}$ content of the glass of CT-52 (with $\mathrm{Au}_{75}-\mathrm{Pd}_{25}$ capsule) by about $4 \%$. Kawamoto and Hirose (1994) reported that the iron loss to the $\mathrm{Au}_{75}-\mathrm{Pd}_{25}$ wire is 3 to $5 \%$ after 48 hours at $1300^{\circ} \mathrm{C}$ under different oxygen fugacity. Therefore, the iron loss of melt to the platinum envelopes at $1262^{\circ} \mathrm{C}$ and 17 hours is small. And, the iron loss of melt to the platinum envelopes at $1238^{\circ} \mathrm{C}$ and 18 hours can be neglected. 
Table 1. The compositions of gabbro and basalts of Chintan.

\begin{tabular}{|c|c|c|c|}
\hline \multirow{2}{*}{ Wt $(\%)$} & \multirow{2}{*}{ This study } & \multicolumn{2}{|c|}{ Chen (1998) } \\
\hline & & CHT-24B ${ }^{1}$ & CHT-24F \\
\hline $\mathrm{SiO}_{2}$ & 47.57 & 46.98 & 48.37 \\
\hline $\mathrm{TiO}_{2}$ & 2.17 & 2.13 & 2.56 \\
\hline $\mathrm{Al}_{2} \mathrm{O}_{3}$ & 14.36 & 14.27 & 14.20 \\
\hline $\mathrm{FeO}$ & 8.48 & 9.55 & 9.80 \\
\hline $\mathrm{MnO}$ & 0.11 & 0.12 & 0.12 \\
\hline $\mathrm{MgO}$ & 4.35 & 5.08 & 4.17 \\
\hline $\mathrm{CaO}$ & 10.15 & 10.02 & 8.78 \\
\hline $\mathrm{Na}_{2} \mathrm{O}$ & 2.63 & 2.06 & 2.78 \\
\hline $\mathrm{K}_{2} \mathrm{O}$ & 1.10 & 0.59 & 1.15 \\
\hline $\mathrm{P}_{2} \mathrm{O}_{5}$ & 0.41 & 0.36 & 0.69 \\
\hline L.O.I. $^{2}$ & 7.38 & 8.02 & 7.27 \\
\hline Total & 98.71 & 99.18 & 99.89 \\
\hline \multicolumn{4}{|c|}{ C.I.P.W. Norm. } \\
\hline Q & 0.52 & 2.42 & 1.84 \\
\hline Or & 6.50 & 3.49 & 6.80 \\
\hline $\mathrm{Ab}$ & 22.25 & 17.43 & 23.52 \\
\hline An & 24.13 & 27.95 & 22.87 \\
\hline Di & 19.56 & 16.12 & 13.52 \\
\hline Hy & 13.30 & 18.88 & 17.61 \\
\hline Il & 4.12 & 4.05 & 4.86 \\
\hline Ap & 0.95 & 0.83 & 1.60 \\
\hline$\%$ An & 52.02 & 61.60 & 49.30 \\
\hline
\end{tabular}

${ }^{I}$ Basalts of dike rocks reported by Chen (1998).

${ }^{2}$ L.O.I. $=$ Loss on ignition.

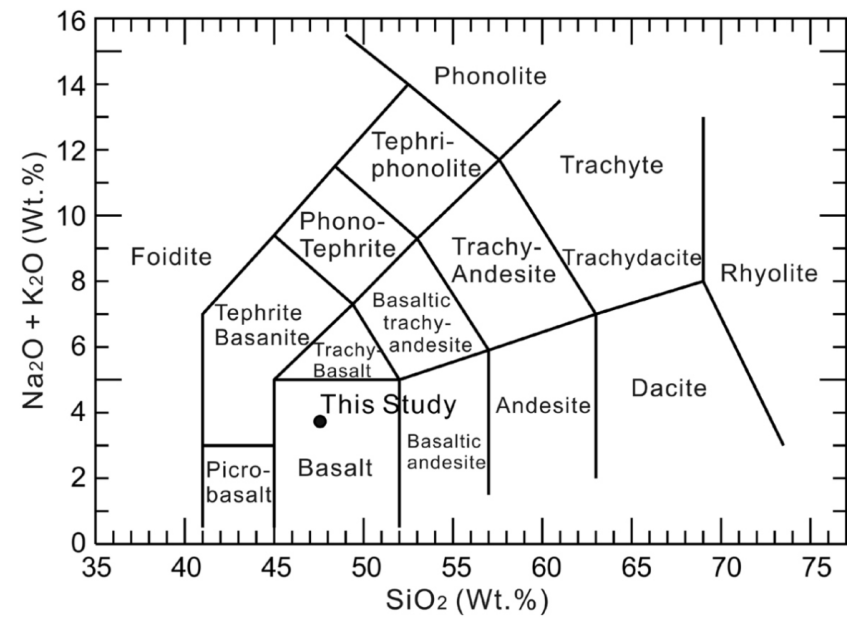

Fig. 2. The classification of the rock composition in this study in the alkali oxide- $\mathrm{SiO}_{2}$ diagram. The boundary lines between different rock types are according to LeBas et al. (1986).
Table 2. Melting experimental runs at atmospheric pressure.

\begin{tabular}{|c|c|c|c|}
\hline Number & $\begin{array}{c}\text { Temp. } \\
\left({ }^{\circ} \mathrm{C}\right)\end{array}$ & $\begin{array}{c}\text { Duration } \\
\text { (hr:min) }\end{array}$ & Phase (s) ${ }^{1}$ \\
\hline CT-34 & 1262 & $17: 05$ & Gl \\
\hline $\mathrm{CT}-52^{2}$ & 1262 & $17: 05$ & Gl \\
\hline CT-27 & 1260 & $17: 05$ & $\mathrm{Gl}+\mathrm{Ox}$ \\
\hline CT-46 & 1242 & $18: 00$ & $\mathrm{Gl}+\mathrm{Ox}$ \\
\hline CT-35 & 1241 & $18: 05$ & $\mathrm{Gl}+\mathrm{Ox}$ \\
\hline CT-49 & 1238 & $18: 05$ & $\mathrm{Gl}+\mathrm{Ox}$ \\
\hline $\mathrm{CT}-51^{2}$ & 1238 & $18: 05$ & $\mathrm{Gl}+\mathrm{Ox}$ \\
\hline CT-47 & 1233 & 18:07 & $\mathrm{Gl}+\mathrm{Ox}$ \\
\hline CT-43 & 1232 & $18: 05$ & $\mathrm{Gl}+\mathrm{Ox}+\mathrm{Pl}$ \\
\hline CT-50 & 1227 & $18: 15$ & $\mathrm{Gl}+\mathrm{Ox}+\mathrm{Pl}$ \\
\hline CT-48 & 1214 & $19: 50$ & $\mathrm{Gl}+\mathrm{Ox}+\mathrm{Pl}$ \\
\hline CT-54 & 1197 & 100:00 & $\mathrm{Gl}+\mathrm{Ox}+\mathrm{Pl}$ \\
\hline CT-55 & 1195 & 100:00 & $\mathrm{Gl}+\mathrm{Ox}+\mathrm{Pl}+\mathrm{Chr}$ \\
\hline CT-08 & 1194 & $20: 13$ & $\mathrm{Gl}+\mathrm{Ox}+\mathrm{Pl}+\mathrm{Chr}$ \\
\hline CT-53 & 1192 & $20: 20$ & $\mathrm{Gl}+\mathrm{Ox}+\mathrm{Pl}+\mathrm{Chr}$ \\
\hline CT-45 & 1179 & $20: 05$ & $\mathrm{Gl}+\mathrm{Ox}+\mathrm{Pl}+\mathrm{Chr}$ \\
\hline CT-41 & 1176 & $20: 00$ & $\mathrm{Gl}+\mathrm{Ox}+\mathrm{Pl}+\mathrm{Chr}+\mathrm{Px}$ \\
\hline CT-37 & 1175 & 20:00 & $\mathrm{Gl}+\mathrm{Ox}+\mathrm{Pl}+\mathrm{Chr}+\mathrm{Px}$ \\
\hline CT-56 & 1173 & 150:00 & $\mathrm{Gl}+\mathrm{Ox}+\mathrm{Pl}+\mathrm{Chr}+\mathrm{Px}$ \\
\hline CT-44 & 1172 & $20: 00$ & $\mathrm{Gl}+\mathrm{Ox}+\mathrm{Pl}+\mathrm{Chr}+\mathrm{Px}$ \\
\hline CT-21 & 1157 & $16: 21$ & $\mathrm{Gl}+\mathrm{Ox}+\mathrm{Pl}+\mathrm{Chr}+\mathrm{Px}$ \\
\hline CT-16 & 1138 & $24: 16$ & $\mathrm{Gl}+\mathrm{Ox}+\mathrm{Pl}+\mathrm{Chr}+\mathrm{Px}$ \\
\hline CT-06 & 1120 & $28: 30$ & $\mathrm{Gl}+\mathrm{Ox}+\mathrm{Pl}+\mathrm{Chr}+\mathrm{Px}$ \\
\hline
\end{tabular}

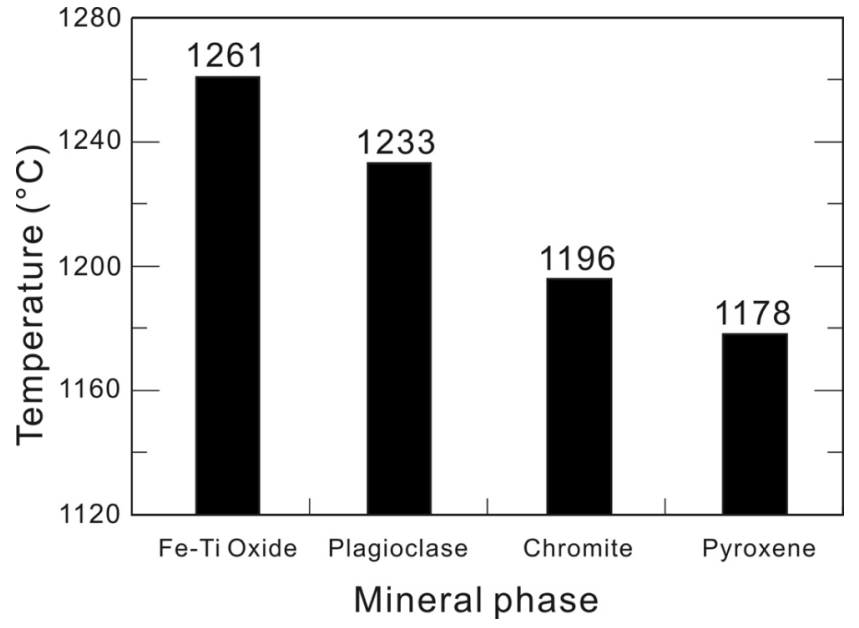

Fig. 3. The crystallization sequence of the Chintan gabbroic melts was determined by the experiments in this study. 
Table 3. The glass compositions in platinum envelopes and $\mathrm{Au}_{75}-\mathrm{Pd}_{25}$ capsules.

\begin{tabular}{ccccc}
\hline $\begin{array}{l}\text { Run no. } \\
\text { Envelope/Capsule }\end{array}$ & $\mathrm{CT}-34$ & $\mathrm{CT}-52$ & $\mathrm{CT}-49$ & $\mathrm{CT}-51$ \\
Temp. $\left({ }^{\circ} \mathbf{C}\right)$ & $\mathrm{Pt}$ & $\mathrm{Au}_{75}-\mathrm{Pd}_{25}$ & $\mathrm{Pt}$ & $\mathrm{Au}_{75}-\mathrm{Pd}_{25}$ \\
Avg. of & 1262 & 1262 & 1238 & 1238 \\
\hline Wt. $(\%)$ & 18 & 9 & 14 & 10 \\
\hline $\mathrm{SiO}_{2}$ & $55.97(0.68)^{1}$ & $55.62(0.92)$ & $55.73(0.87)$ & $55.54(0.51)$ \\
$\mathrm{Al}_{2} \mathrm{O}_{3}$ & $16.33(0.47)$ & $16.41(0.73)$ & $16.42(0.70)$ & $16.59(0.52)$ \\
$\mathrm{HFO}$ & $8.82(0.65)$ & $9.16(0.91)$ & $8.96(0.67)$ & $8.91(0.49)$ \\
$\mathrm{MgO}$ & $4.74(0.38)$ & $4.84(0.43)$ & $4.55(0.35)$ & $4.76(0.35)$ \\
$\mathrm{CaO}$ & $10.37(0.44)$ & $10.65(0.49)$ & $10.66(0.45)$ & $10.75(0.58)$ \\
$\mathrm{Na}{ }_{2} \mathrm{O}$ & $3.44(0.37)$ & $3.32(0.23)$ & $3.35(0.38)$ & $3.45(0.37)$ \\
$\mathrm{K}_{2} \mathrm{O}$ & $0.33(0.74)$ & $0.00(0.00)$ & $0.33(0.64)$ & $0.00(0.00)$ \\
Total & 100.00 & 100.00 & 100.00 & 100.00 \\
\hline C.I.P.W. Norm. & & & & 2.98 \\
\hline $\mathrm{Q}$ & 3.07 & 3.57 & 3.07 & - \\
$\mathrm{Or}$ & 1.95 & - & 1.95 & 29.19 \\
$\mathrm{Ab}$ & 29.11 & 28.09 & 28.35 & 29.78 \\
$\mathrm{An}$ & 28.14 & 29.87 & 28.79 & 19.7 \\
$\mathrm{Di}$ & 19.49 & 19.21 & 20.19 & 18.35 \\
$\mathrm{Hy}$ & 18.24 & 19.25 & 17.66 & 50.50 \\
\% An & 49.16 & 51.54 & 50.39 & \\
\hline
\end{tabular}

${ }^{I}$ Standard deviation of the mean in parentheses.

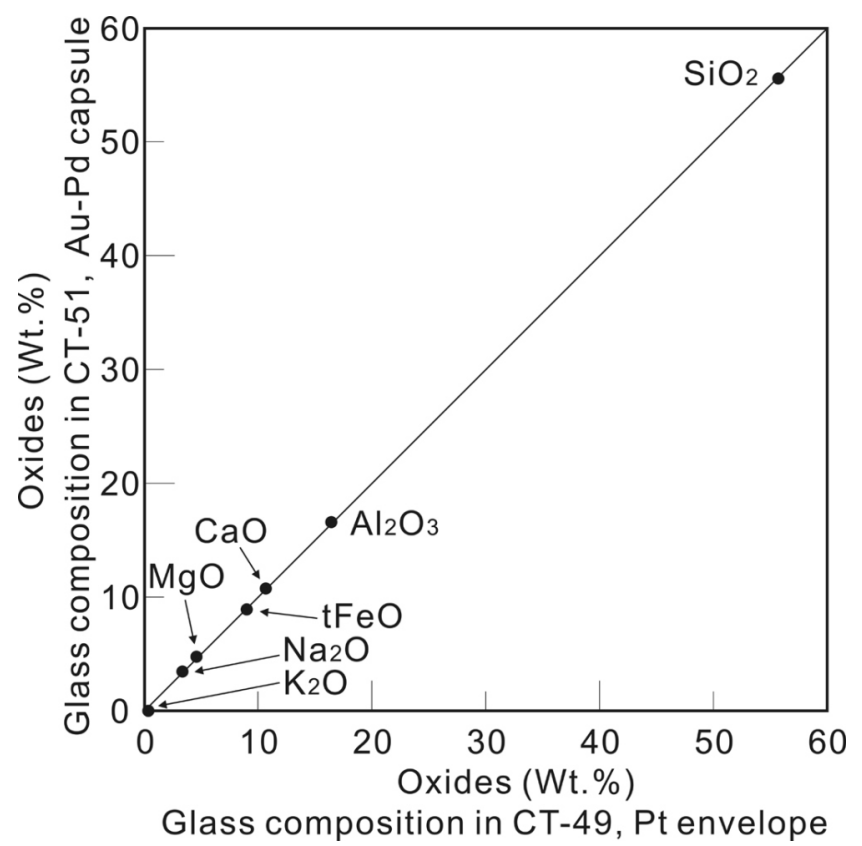

Fig. 4. Comparison between glass composition in CT- $49\left(1238^{\circ} \mathrm{C}\right.$; platinum envelope) and glass composition in CT-51 $\left(1238^{\circ} \mathrm{C} ; \mathrm{Au}_{75}-\mathrm{Pd}_{25}\right.$ capsules). The standard deviations of oxides are smaller than the dots in the figure. The slope of the straight line is 1 .

\subsection{Compositions of the Synthetic Phases versus Natural Minerals of Chintan Igneous Rocks}

The synthesized plagioclases were analyzed and are listed in Table 4. Plagioclase crystallized at $1233^{\circ} \mathrm{C}$, and the sizes of synthesized plagioclases are larger at lower temperature and with longer duration. The synthesized plagioclases are extensively present between 1232 and $1120^{\circ} \mathrm{C}$. In the back-scattered electron imaging (BEI) of SEM, synthesized plagioclases are homogeneous in composition. The anorthite (An) contents of synthesized plagioclases (between 1232 and $1172^{\circ} \mathrm{C}$ ) are from 64 to $67 \mathrm{~mol} \%$. In Chintan alkali basalts, the An contents of plagioclase phenocrysts range from 63 to $67 \mathrm{~mol} \%$ (Chen 1998). They are very similar. The plagioclases of Chintan teschenites, however, contain anorthite component from 40 to $73 \mathrm{~mol} \%$, implying that the fractional crystallization of the Chintan alkali basaltic magma produced the wide compositional spectrum of plagioclase.

Pyroxene crystallized at temperatures lower than $1178^{\circ} \mathrm{C}$. As the temperature decreases, the sizes of synthesized pyroxenes also become larger. The synthesized pyroxenes were analyzed and the compositions of synthesized pyroxenes are 
Table 4. Chemical compositions of synthesized plagioclases in this study.

\begin{tabular}{|c|c|c|c|c|c|}
\hline Run No. & CT-43 & CT -50 & CT -45 & CT-41 & CT-44 \\
\hline Temp. $\left({ }^{\circ} \mathrm{C}\right)$ & 1232 & 1227 & 1179 & 1176 & 1172 \\
\hline Avg. of & 2 & 2 & 16 & 10 & 3 \\
\hline \multicolumn{6}{|l|}{ Wt. (\%) } \\
\hline $\mathrm{SiO}_{2}$ & $54.70(0.59)^{1}$ & $53.59(0.09)$ & $53.91(1.08)$ & $53.98(0.91)$ & $55.75(1.50)$ \\
\hline $\mathrm{Al}_{2} \mathrm{O}_{3}$ & $27.73(0.61)$ & $28.01(0.26)$ & $28.32(0.81)$ & $28.39(0.65)$ & $27.64(0.77)$ \\
\hline $\mathrm{MgO}$ & $0.97(0.04)$ & $1.00(0.11)$ & $0.58(0.52)$ & $0.00(0.00)$ & $0.00(0.00)$ \\
\hline $\mathrm{CaO}$ & $12.82(0.11)$ & $13.72(0.42)$ & $13.37(0.72)$ & $13.72(0.77)$ & $12.59(0.69)$ \\
\hline $\mathrm{Na}_{2} \mathrm{O}$ & $3.79(0.11)$ & $3.69(0.04)$ & $3.81(0.17)$ & $3.91(0.68)$ & $4.02(0.26)$ \\
\hline Total & 100.00 & 100.00 & 100.00 & 100.00 & 100.00 \\
\hline \multicolumn{6}{|c|}{ Cations per 8 Oxygens } \\
\hline $\mathrm{Si}$ & 2.468 & 2.429 & 2.439 & 2.445 & 2.480 \\
\hline $\mathrm{Al}$ & 1.475 & 1.497 & 1.511 & 1.516 & 1.490 \\
\hline $\mathrm{Mg}$ & 0.065 & 0.068 & 0.039 & 0.000 & 0.000 \\
\hline $\mathrm{Ca}$ & 0.620 & 0.666 & 0.648 & 0.666 & 0.628 \\
\hline $\mathrm{Na}$ & 0.331 & 0.324 & 0.335 & 0.343 & 0.354 \\
\hline K & 0.000 & 0.000 & 0.000 & 0.000 & 0.000 \\
\hline Total & 4.960 & 4.984 & 4.972 & 4.969 & 4.952 \\
\hline $\mathrm{An}^{2}$ & 65 & 67 & 66 & 66 & 64 \\
\hline $\mathrm{Ab}^{3}$ & 35 & 33 & 34 & 34 & 36 \\
\hline $\mathrm{Or}^{4}$ & 0 & 0 & 0 & 0 & 0 \\
\hline
\end{tabular}

${ }^{1}$ Standard deviation of the mean in parentheses.

${ }^{2} \mathrm{An}=\mathrm{CaAl}_{2} \mathrm{Si}_{2} \mathrm{O}_{8}$.

${ }^{3} \mathrm{Ab}^{2}=\mathrm{NaAlSi}_{3} \mathrm{O}_{8}$

${ }^{4} \mathrm{Or}=\mathrm{KAlSi}_{3} \mathrm{O}_{8}$

listed in Table 5. The compositions of the synthesized pyroxenes at 1176 and $1172^{\circ} \mathrm{C}$ are similar. The $\mathrm{SiO}_{2}$ and $\mathrm{Al}_{2} \mathrm{O}_{3}$ of pyroxenes at $1176^{\circ} \mathrm{C}$ are slightly lower than those of pyroxenes at $1172^{\circ} \mathrm{C}$. The $\mathrm{FeO}$ and $\mathrm{MgO}$ of pyroxenes at $1176^{\circ} \mathrm{C}$ are a little higher than those of pyroxenes at lower temperatures. The compositions of synthesized pyroxenes are close to the compositions of natural pyroxenes of syenites in Chin$\tan$ (Fig. 5). They are classified as diopsides/augites following the classification of Morimoto (1988).

\subsection{Evolution of the Gabbroic Melt at Chintan}

At the end of the high temperature experiments, the residual melts were quenched into glasses. The glasses in eleven runs, between 1262 and $1172^{\circ} \mathrm{C}$, were analyzed and are listed in Table 6 . All of the glass compositions were normalized to $100 \%$.

The compositions of glasses in Table 6 were plotted versus experimental temperature in Fig. 6. The fractionation trends show that the residual melts become enriched in silicon and magnesium as the temperature decreases, reading from high temperature on the right to low temperature on the left. The residual melts become depleted in aluminum and iron with cooling. The sodium in the residual melts does not change significantly as the temperature decreases. The fractionation trend shows that the residual melts do not change significantly in $\mathrm{MgO}$ and $\mathrm{FeO}$ through fractionation of trace amount of Fe-Ti oxides in the early stage. The standard deviations of $\mathrm{FeO}$ in glasses (Table 6) are higher than the variations in glasses between 1233 and $1262^{\circ} \mathrm{C}$. This also implies that there is a slight influence with small amounts of Fe-Ti oxides. The fractionation of Chintan gabbroic melt was joined by the crystallization of small amounts of plagioclase in the middle stage and shows slight depletion of $\mathrm{Al}_{2} \mathrm{O}_{3}$ and $\mathrm{CaO}$ of the residual liquids. In Table 6, the $\mathrm{Q}, \mathrm{Ab}$, $\mathrm{An}, \mathrm{Di}$, and Hy norms of the residual melts did not show an 
apparent consistent variations through all the fractionation in the experiments.

The eleven residual liquid compositions were also plotted with four rock type compositions from Chen (1998) in variation diagrams as in Fig. 7. The whole rock composition of the starting material in this study was normalized to $100 \%$ without loss on ignition and was plotted as an open circle in the middle of Fig. 7. There is a difference of about $3.9 \%$ of $\mathrm{SiO}_{2}$ between the starting composition analyzed with XRF and the melt composition at $1262^{\circ} \mathrm{C}$ analyzed with SEM and EDS (Run no. CT-34). The difference may be caused by the systematic error between the XRF analysis and EDS analysis. This may be partly caused by the compositional change during melting in the XRF sample preparation and the melting experiments at high temperature. The exact cause could not be determined in this study.

Chen (1998) suggested that alkali basaltic magma fractionated teschenite in the base of the magma chamber. The residual melt fractionated into microsyenites and alkali feld-

Table 5. Chemical compositions of synthesized pyroxenes in this study.

\begin{tabular}{|c|c|c|}
\hline Run No. & CT-41 & CT-44 \\
\hline Temp. $\left({ }^{\circ} \mathrm{C}\right)$ & 1176 & 1172 \\
\hline Avg. of & 4 & 8 \\
\hline \multicolumn{3}{|l|}{ Wt. $(\%)$} \\
\hline $\mathrm{SiO}_{2}$ & $50.30(0.73)^{1}$ & $51.56(0.57)$ \\
\hline $\mathrm{Al}_{2} \mathrm{O}_{3}$ & $5.88(0.69)$ & $6.76(0.56)$ \\
\hline $\mathrm{FeO}$ & $10.46(0.63)$ & $9.21(0.74)$ \\
\hline $\mathrm{MgO}$ & $13.65(0.40)$ & $12.90(0.32)$ \\
\hline $\mathrm{CaO}$ & $19.71(0.91)$ & $19.58(0.57)$ \\
\hline Total & 100.00 & 100.00 \\
\hline \multicolumn{3}{|c|}{ Cations per 6 Oxygens } \\
\hline $\mathrm{Si}$ & 1.872 & 1.889 \\
\hline $\mathrm{Al}$ & 0.258 & 0.282 \\
\hline $\mathrm{Fe}$ & 0.325 & 0.298 \\
\hline $\mathrm{Mg}$ & 0.757 & 0.724 \\
\hline $\mathrm{Ca}$ & 0.786 & 0.777 \\
\hline Total & 4.000 & 3.970 \\
\hline $\mathrm{Wo}^{2}$ & 42 & 43 \\
\hline $\mathrm{Fs}^{3}$ & 17 & 17 \\
\hline $\mathrm{En}^{4}$ & 41 & 40 \\
\hline $\begin{array}{l}\text { andard deviatio } \\
o=\mathrm{CaSiO}_{3} . \\
=\mathrm{FeSiO}_{3} . \\
\imath=\mathrm{MgSiO}_{3} .\end{array}$ & ean in parenthes & \\
\hline
\end{tabular}

spar syenite. In Fig. 7, the teschenites, microsyenites, basalts, and alkali feldspar syenites line up on a liquid line of desent. If the amounts of $\mathrm{SiO}_{2}$ in all the residual melts in this study are decreased by about $3.9 \%$, for the reason mentioned above, the whole residual melts fit properly in the liquid line of descent in the $\mathrm{SiO}_{2}$ versus $\mathrm{Al}_{2} \mathrm{O}_{3}$ diagram. The $\mathrm{MgO}$ of the residual melts in this study are higher than those of the natural alkali feldspar syenites shown in the $\mathrm{MgO}$ versus $\mathrm{SiO}_{2}$ diagram (Fig. 7). The residual melts in this study need to fractionate more pyroxenes to approach the natural alkali feldspar syenites.

The melt compositions in this study and the four rock types of Chintan are also plotted in an AFM diagram as in Fig. 8. Teshenites, basalts, microsyenites, and alkali feldspar syenites form a trend. The basaltic magma can differentiate into microsyenites and alkali feldspar syenites. The synthesized phases in this study were also plotted in Fig. 8. The fractional crystallization of the gabbroic liquid at atmospheric pressure is controlled by the iron-titanium oxides, plagioclase, chromite, and pyroxene (Table 2). In Fig. 8, the differentiation trend of the gabbroic melts move

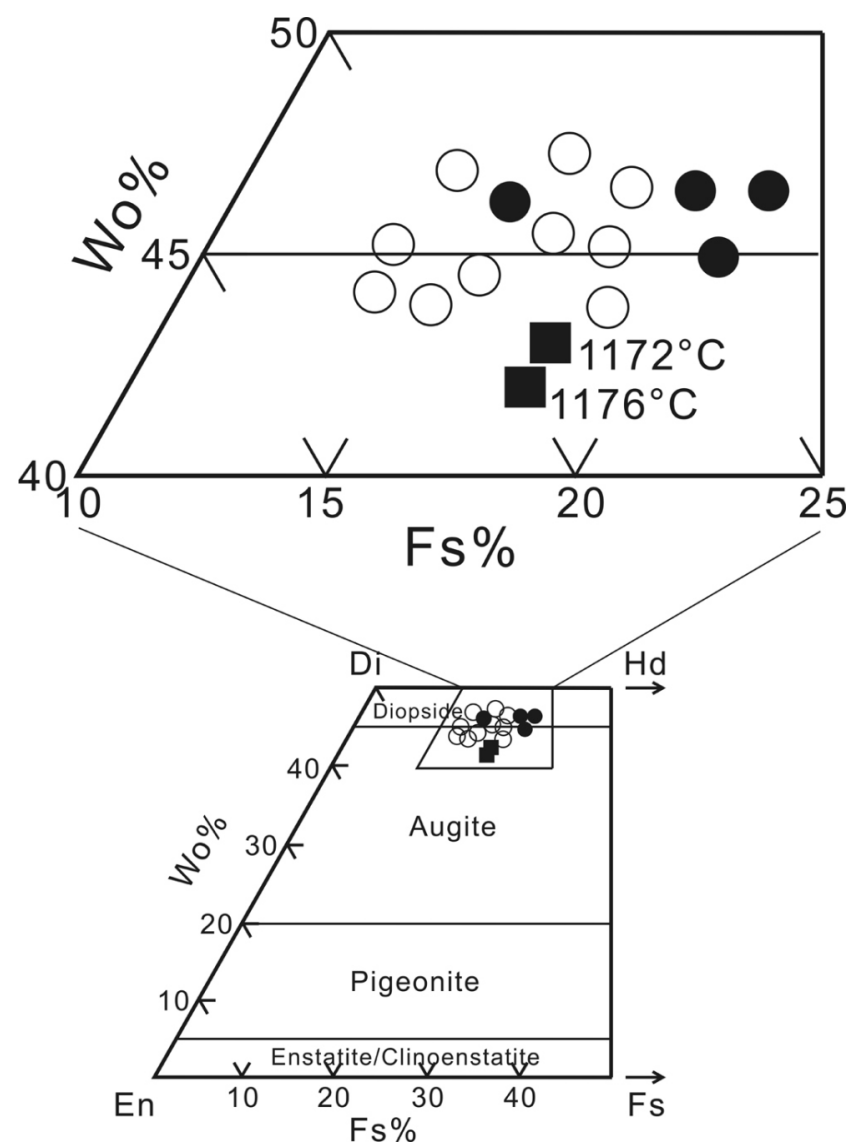

Fig. 5. The compositions of synthetic pyroxenes and natural clinopyroxenes of Chintan. Solid squares: the synthesized pyroxenes in this study; open circles and solid dots represent clinopyroxene in microsyenites and alkali feldspar syenites of Chintan, respectively (Chen 1998). The boundary lines were drawn after Morimoto (1988). 
Table 6. Chemical compositions of the glasses in this study.

\begin{tabular}{|c|c|c|c|c|c|c|c|c|c|c|c|}
\hline Run no. & CT-34 & CT-27 & CT-46 & CT-35 & CT -49 & CT -47 & CT -43 & CT -50 & CT -45 & CT-41 & CT-44 \\
\hline Temp. $\left({ }^{\circ} \mathrm{C}\right)$ & 1262 & 1260 & 1242 & 1241 & 1238 & 1233 & 1232 & 1227 & 1179 & 1176 & 1172 \\
\hline Avg. of & 18 & 18 & 20 & 12 & 14 & 11 & 5 & 8 & 4 & 12 & 8 \\
\hline \multicolumn{12}{|l|}{ Wt. (\%) } \\
\hline $\mathrm{SiO}_{2}$ & $55.97(0.68)^{1}$ & ${ }^{1} 55.57(0.82)$ & $55.47(0.61)$ & $56.16(0.71)$ & $55.73(0.87)$ & $55.15(0.62)$ & $55.55(0.83)$ & $56.10(0.71)$ & $56.48(0.98)$ & $57.28(0.76)$ & $56.91(0.70)$ \\
\hline $\mathrm{Al}_{2} \mathrm{O}_{3}$ & $16.33(0.47)$ & $16.57(0.47)$ & $16.38(0.70)$ & $16.22(0.71)$ & $16.42(0.70)$ & $16.26(0.70)$ & $16.49(0.62)$ & $16.49(0.75)$ & $14.96(0.42)$ & $14.71(0.38)$ & $14.64(0.36)$ \\
\hline $\mathrm{tFeO}$ & $8.82(0.65)$ & $8.85(0.72)$ & $8.98(0.53)$ & $8.53(0.63)$ & $8.96(0.67)$ & $9.11(0.71)$ & $8.85(0.49)$ & $8.73(0.66)$ & $7.99(0.56)$ & $7.86(0.61)$ & $7.64(0.39)$ \\
\hline $\mathrm{MgO}$ & $4.74(0.38)$ & $4.63(0.34)$ & $4.67(0.33)$ & $4.63(0.27)$ & $4.55(0.35)$ & $4.58(0.42)$ & $4.85(0.36)$ & $4.66(0.22)$ & $5.17(0.20)$ & $5.27(0.43)$ & $5.64(0.37)$ \\
\hline $\mathrm{CaO}$ & $10.37(0.44)$ & $10.76(0.55)$ & $10.61(0.40)$ & $10.64(0.42)$ & $10.66(0.45)$ & $10.85(0.51)$ & $10.86(0.48)$ & $10.63(0.41)$ & $11.01(0.20)$ & $11.05(0.58)$ & $10.91(0.63)$ \\
\hline $\mathrm{Na}_{2} \mathrm{O}$ & $3.44(0.37)$ & $3.31(0.22)$ & $3.40(0.28)$ & $3.57(0.41)$ & $3.35(0.38)$ & $3.43(0.22)$ & $3.41(0.14)$ & $3.39(0.32)$ & $3.51(0.22)$ & $3.22(0.38)$ & $3.23(0.27)$ \\
\hline $\mathrm{K}_{2} \mathrm{O}$ & $0.33(0.74)$ & $0.31(0.69)$ & $0.49(0.72)$ & $0.25(0.56)$ & $0.33(0.64)$ & $0.62(0.82)$ & $0.00(0.00)$ & $0.00(0.00)$ & $0.86(0.87)$ & $0.60(0.85)$ & $1.03(0.81)$ \\
\hline Total & 100.00 & 100.00 & 100.00 & 100.00 & 100.00 & 100.00 & 100.00 & 100.00 & 100.00 & 100.00 & 100.00 \\
\hline \multicolumn{12}{|c|}{ C.I.P.W. Norm. } \\
\hline Q & 3.07 & 2.94 & 1.94 & 3.07 & 3.07 & 0.89 & 3.04 & 4.31 & 1.72 & 4.82 & 2.86 \\
\hline Or & 1.95 & 1.83 & 2.90 & 1.48 & 1.95 & 3.66 & - & - & 5.08 & 3.55 & 6.09 \\
\hline $\mathrm{Ab}$ & 29.11 & 28.01 & 28.77 & 30.21 & 28.35 & 29.02 & 28.85 & 28.69 & 29.70 & 27.25 & 27.33 \\
\hline An & 28.14 & 29.44 & 27.99 & 27.49 & 28.79 & 27.14 & 29.69 & 29.78 & 22.52 & 23.91 & 22.41 \\
\hline Di & 19.49 & 20.04 & 20.64 & 21.14 & 20.19 & 22.37 & 20.22 & 19.20 & 26.67 & 25.65 & 26.24 \\
\hline Hy & 18.24 & 17.74 & 17.78 & 16.61 & 17.66 & 16.91 & 18.21 & 18.02 & 14.28 & 14.81 & 15.08 \\
\hline$\%$ An & 49.16 & 51.25 & 49.31 & 47.65 & 50.39 & 48.32 & 50.71 & 50.93 & 43.13 & 46.74 & 45.05 \\
\hline
\end{tabular}

${ }^{1}$ Standard deviation of the mean in parentheses.

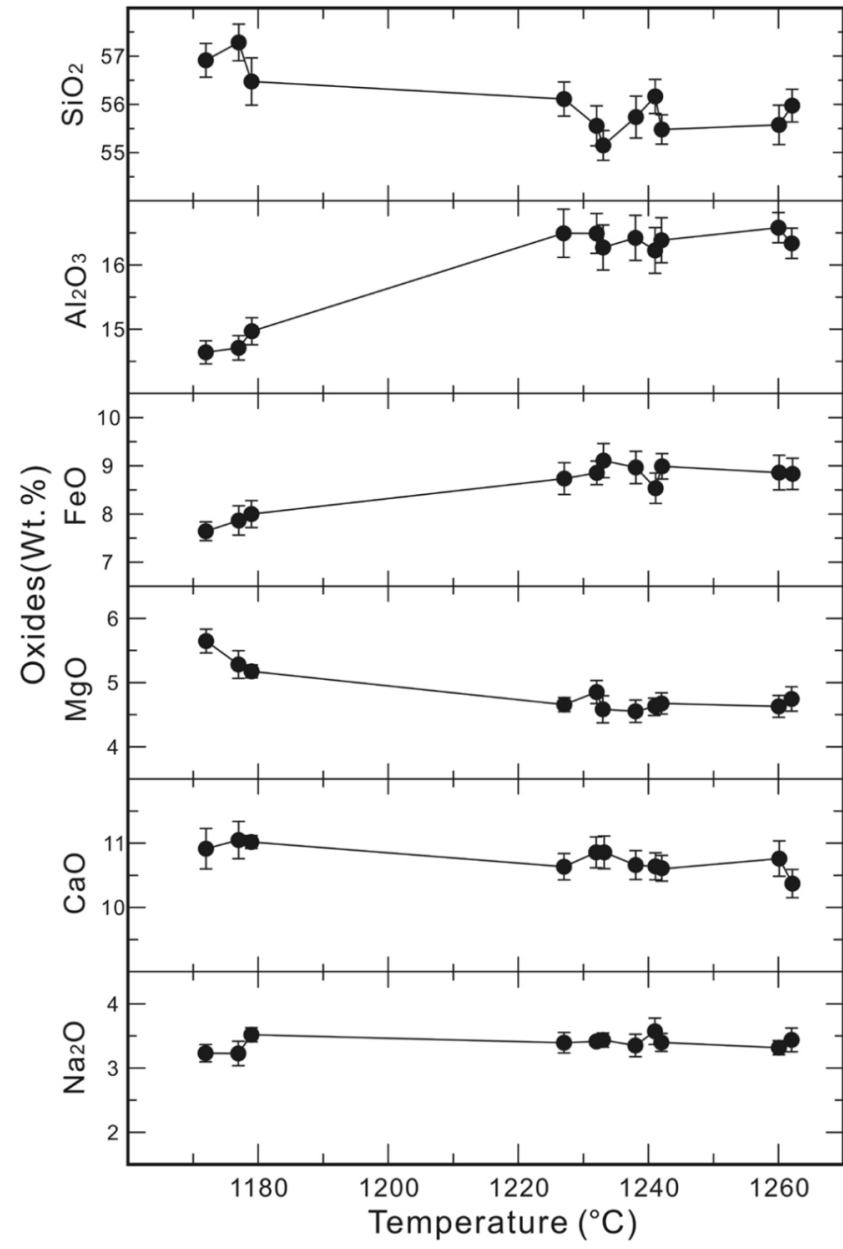

Fig. 6. The variation of glass compositions versus temperatures. The error bars are the standard deviations of the oxides. around in the center of the AFM diagram and is not supported by the model proposed by Chen (1998). Since this study was only performed at atmospheric pressure, the results of this study can only be applied to the fractionation of gabbroic melt occurred on the ground or at a shallow depth and under an anhydrous condition. The evolution of the Chintan gabbroic melt may be clarified with the investigation of the fractionation of the gabbroic melt at high pressures.

\section{SUMMARY}

The results of this study show that the liquidus temperature of the gabbro of Chintan is about $1261^{\circ} \mathrm{C}$. From the crystallization sequence and temperatures of the gabbroic melt at atmospheric pressure, it was determined that $\mathrm{Fe}-\mathrm{Ti}$ oxides crystallized first at $1261^{\circ} \mathrm{C}$. Plagioclase and chromite crystallized at 1233 and $1196^{\circ} \mathrm{C}$, respectively. Finally, pyroxene crystallized at $1178^{\circ} \mathrm{C}$. The solidus temperature of the gabbroic melt is at $1110^{\circ} \mathrm{C}$. The melting interval is estimated to be about $151^{\circ} \mathrm{C}$.

Comparing the experiments with platinum envelopes and $\mathrm{Au}_{75}-\mathrm{Pd}_{25}$ capsules, the compositions of the glasses in different experimental envelopes are similar. The iron loss of melt to the platinum envelopes at $1238^{\circ} \mathrm{C}$ over 18 hours can be neglected.

The fractional crystallization of the gabbroic melt at atmospheric pressure is controlled by iron-titanium oxides, plagioclase, chromite, and pyroxene. The differentiation trend of the gabbroic melts moves around in the center of the 


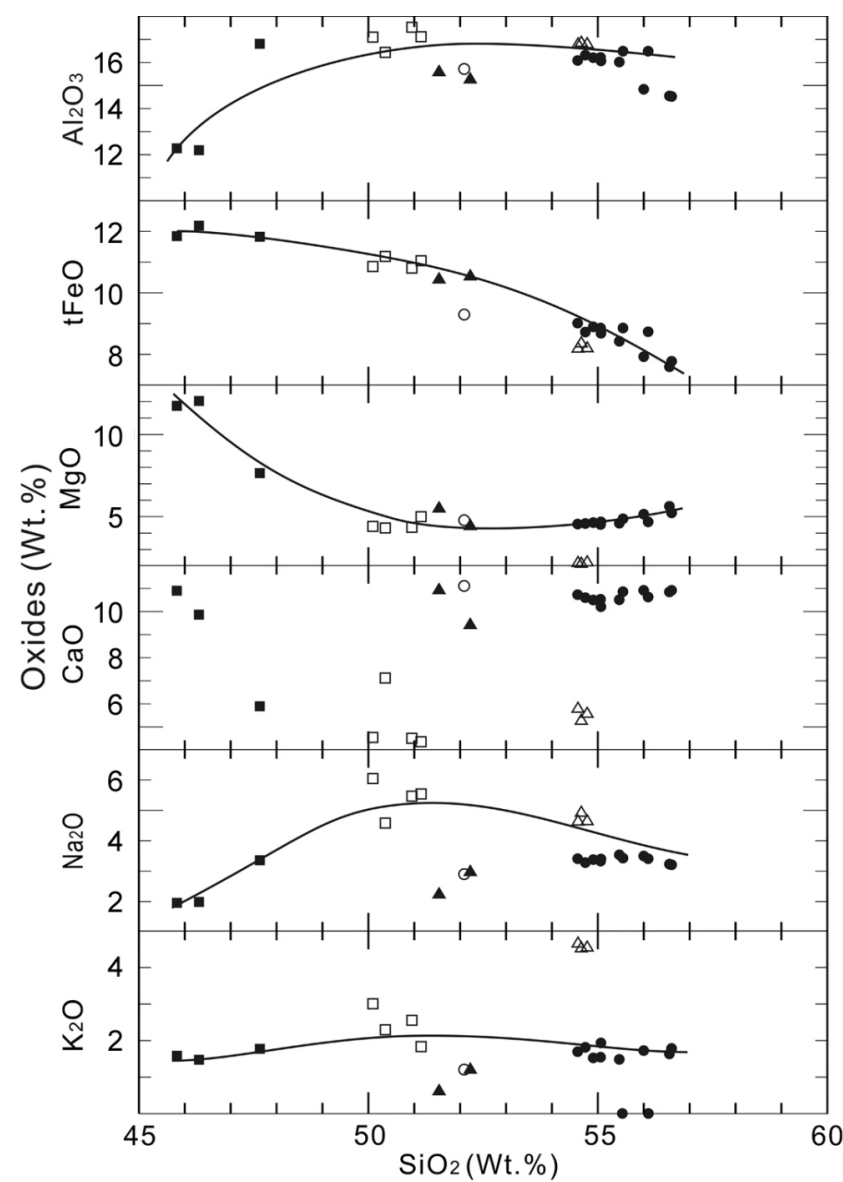

Fig. 7. Harker's variation diagrams for the glasses in quenching products and Chintan igneous rocks (Chen 1998). The oxides compositions of Chintan rocks were normalized to $100 \%$. Symbols: solid dots: melts in this study; open circles: whole rock composition of the starting material in this study analyzed by XRF. Rocks of Chintan from Chen (1998): solid squares: teschenites; open squares: microsyenites; solid triangles: basalts; open triangles: alkali feldspar syenites; solid line: liquid line of descent drawn tentatively.

AFM diagram and can not fractionate into microsyenitic and alkali feldspar syenitic melts.

Acknowledgements Two anonymous reviewers were very helpful in suggesting improvements to the manuscript. We would like to thank Professor Ju-Chin Chen and his students at National Taiwan University for pulverization of the gabbro in this study. We are also indebted to Dr. Chi-Yu Lee, National Taiwan University, for the XRF analysis of the gabbro. Our gratitude also goes to the Academic Paper Editing Clinic, NTNU. This study was supported by the Nation Science Council, ROC, under grant NSC95-2815C-003-011-M to TCL and JWH.

\section{REFERENCES}

Biggar, G. M., 1972: Diopside, lithium metasilicate, and the 1968 temperature scale. Mineral. Mag., 38, 768-770.

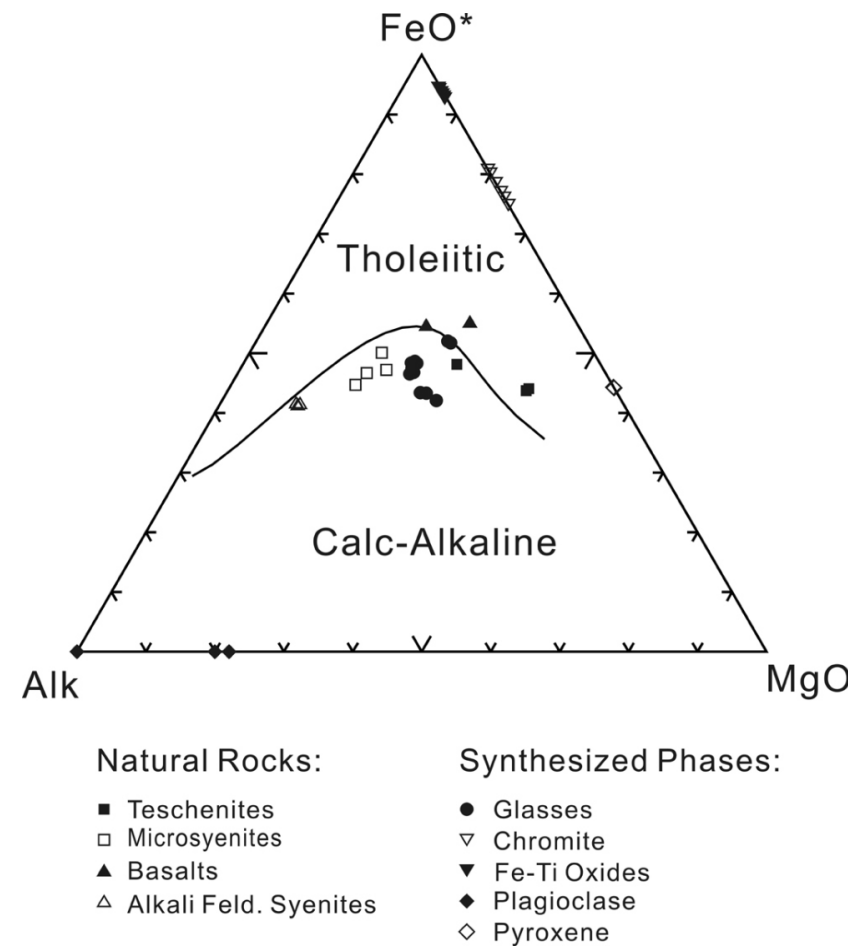

Fig. 8. AFM diagram of the glasses in this study and the rocks of Chintan from Chen (1998). Symbols are the same as in Fig. 7. The compositions of chromite, Fe-Ti oxides, plagioclases and pyroxenes are also plotted for discussion. The boundary line between the tholeiitic series and calc-alkaline series was reproduced after Kuno (1950).

Chen, C. H., 1990: The igneous rock of Taiwan. Geology of Taiwan series 1, Central Geol. Surv. MOEA, ROC, 137 pp. (in Chinese)

Chen, C. H., 1998: Alkali syenites and associated rocks in Chintan, Northern Taiwan: A reappraisal. J. Geol. Soc. China, 41, 337-358.

Ichimura, T., 1929: Brief notes on the alkaline rocks of Taiwan. Trans. Nat. His. Soc. Formosa, 19, 376-381. (in Japanese)

Ichimura, T., 1943: Alkali syenite and its accompanying mother rock in Chintan, Taipei County. Trans. Nat. His. Soc. Formosa, 33(240), 229-244. (in Japanese)

Iizuka, Y., P. Bellwood, H. C. Hung, and E. Z. Dizon., 2005: A non-destructive mineralogical study of nephritic artifacts from Itbayat Island, Batanes, northern Philippines. Journal of Austronesian Studies, 1(1), 80-105.

Kawamoto, T. and K. Hirose, 1994: Au-Pd sample containers for melting experiments on iron and water bearing systems. Eur. J. Mineral., 6, 381-385.

Kuno, H., 1950: Petrology of Hakone volcano and the adjacent areas, Japan. Bull. Geol. Soc. Am., 61, 957-1200.

LeBas, M. J., R. W. LeMaitre, A. Streckeisen, and B. Zanettin, 1986: A chemical classification of volcanic rocks based on the total alkali-silica diagram. J. Petrol., 27, 745-750, doi: 10.1093/petrology/27.3.745. [Link] 
Lee, C. Y., J. H. Tsai, H. H. Ho, F. T. Yang, S. L. Chung, and C. H. Chen., 1997: Quantitative analysis in rock samples by an X-ray fluorescence spectrometer (I) Major elements. Annu. Meet. Geol. Soc. China, 418-420. (in Chinese)

Lin, C. C., 2000: Geologic Map and Explanatory Text of Taiwan, scale 1:50000, sheet 9, Hsintien. Central Geol. Surv., MOEA, ROC, 77 pp. (in Chinese)

Liu, T. C., B. S. Chen, J. J. Pan, P. K. Chen, and S. Z. Wu, 1997 : A preliminary report on the experimental study of the two-pyroxene andesite from Kuanyinshan, Northern Taiwan. J. Nat. Taiwan Normal Univ.: Math., Sci., Tech., 42, 53-59.

Morimoto, N., 1988: Nomenclature of pyroxenes. Mineral. Petrol., 39, 55-76, doi: 10.1007/BF01226262. [Link]
Nesse, W. D., 1991: Introduction to optical mineralogy. Oxford Univ. Press, $335 \mathrm{pp}$.

Sun, S. C., 1982: The Tertiary basins offshore Taiwan. Proc. $2^{\text {nd }}$ ASCOPE Conf. and Exhib., Oct. 7 - 11, Manila, Philippine, 125-135.

Tobi, A. C. and H. Kroll, 1975: Optical determination of the An-content of plagioclases twinned by the Carlsbad-law: A revised chart. Am. J. Sci., 275, 731-736. [Link]

Yen, T. P., 1954: Alkali-syenite rocks in Taiwan. Formosan Sci., 8, 55-56.

Yoder, H. S. Jr. and C. E. Tilley, 1962: Origin of basalt magmas: An experimental study of natural and synthetic rock systems. J. Petrol., 3, 342-532, doi: 10.1093/petrology/3.3. 342. [Link] 